\title{
Academic Supervision toward Teacher's Performance through Motivation as Intervening Variable
}

\author{
Hendro Prasetyono*, Agus Abdillah, Dona Fitria \\ Department of Education Economic, Indraprasta PGRI University, Indonesia
}

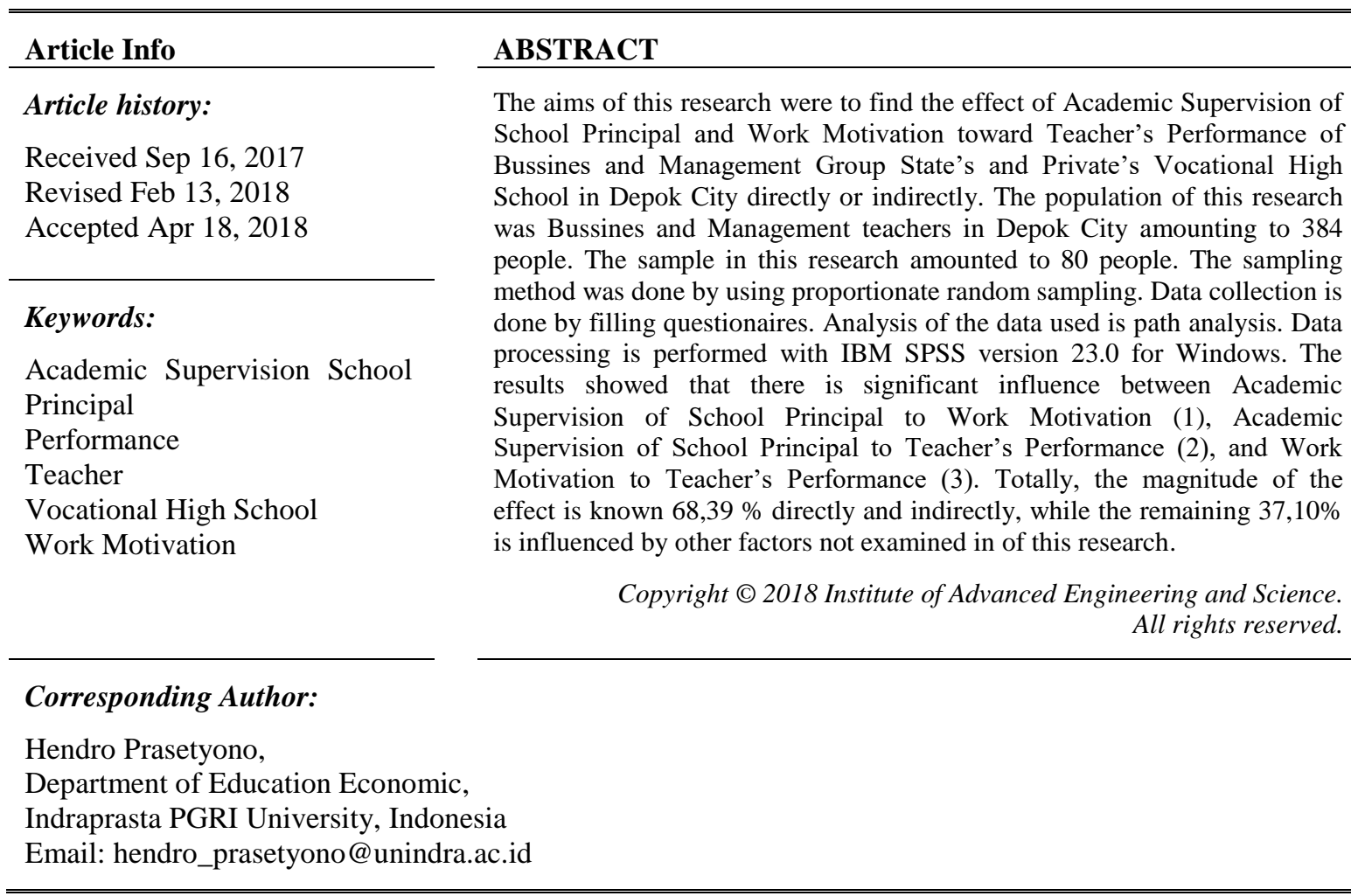

\section{INTRODUCTION}

\subsection{Background}

Vocational High School (VHS) is one type of high school that has the characteristics, requirements and an important role in preparing skilled workers to support national development. In Guidelines of Taching Program of the Second Book, The purpose of Vocational High School is to prepare students to enter the employment and develop professional nature and able to choose career, competence and develop themselves to fill the needs of the business world and industry. In addition, Vocational High School also prepares graduates to be productive, innovative and creative citizens. Teachers are part of the school's residents functioning as managers of the teaching and learning process. As teachers and educators, teachers are one of the critical success factors of every educational effort. A teacher as educators and implementers of education is instrumental in the achievement of educational success to create quality human resources.

Teacher is one of human resources who are in school. Teacher performance has an important role in achieving school goals.According to the law of teachers and lecturers no.14 of 2005 Article 1 paragraph 1 stated that the teacher is a professional educator with the main task of educating, teaching, guiding, directing, training, assessing and evaluating learners on early childhood education formal education, education Basic and secondary education. Thus, the more qualified teachers the greater their contribution to students' selfdevelopment and development of society. The main task of the teacher is an indicator that will be used to measure the performance of teachers in performing their duties.

From the preliminary observations that have been done by the author in prasurvei VHS State and Private Depok city, indicating that there are still teachers who have not performed optimally. The data shows 
on average only $77.96 \%$ of teachers perform well, the remaining $22.04 \%$ of teachers performing in special attention. This means that teachers in special attention perform less adequate, need special guidance and coaching as well. In reality there are still many teachers have not carried their professional duties as teachers. This indicates that the performance is not yet optimal. If there is no meaningful follow-up, then the implication is that the quality of vocational education will decrease, the people less trust especially the business world and industry world full of hesitations in recruiting labor supplied from VHS. If there is no meaningful follow-up, then the implication is that the quality of vocational education will decrease, the people are less trustworthy and the industrial and business world is full of hesitations in recruiting labor supplied from VHS.

Every teacher performance problems emerged, a very important contributing factor is motivation. Motivation is a driving force that can direct a person's behavior in achieving its goals. People who have high motivation will strive strongly to achieve goals, so that his behavior and actions are directed at efforts to achieve those goals. As proposed by Armstrong and Baron in Wibowo [1] the factors that affect performance, including the level of skills, competencies, achievement motivation and individual commitment.

From the observations made in some schools shows still low motivation of teacher work. The low motivation of teachers work, the author assumes that this can happen also in other VHSs in Depok city. The low motivation of teacher work is shown from several indicators by $23.07 \%$. This means that most teachers have a working motivation of only $76.93 \%$. This shows that the motivation of teachers do not work as expected because it should be $100 \%$ in other words all teachers have motivation to work. Therefore, teacher work motivation is said not yet optimal or still low.

Factors that affect teacher performance in addition to internal factors such as work motivation can also be influenced by external factors. An external factor to be raised in this study is about academic supervision. The author deliberately chose the factor of academic supervision because this factor is allegedly to be an instrument of quality evaluation of education in this case concerning the performance of teachers. In the initial observation, including through informal direct interviews to some teachers, teachers often complain because if supervision is done, whether supervision is done by the principal or other parties such as school supervisors, they think that supervision is done as if to look for errors, looking for flaws that have no problem-solving. The nature of supervision is the effort to improve the quality of learning through coaching, development of the ability of teachers to be more professional. Therefore, the supervision is interesting to be appointed as one of the factors that cause the increase or decrease of teacher performance.

Teacher performance problems will always be prominent and actual to be discussed, and how appropriate measures will be in the effort to address the problem. Some of the factors that are on the rise or declining performance of teachers, many researchers have done. However, so far studies have not yet shown the expected solution. The tendency of previous research is to conduct research to analyze the influence of dependent variable on the dependent variable. The purpose of the studies that have been done is limited to simple regression analysis and multiple regressions. Therefore, the author tries to present another approach, with path analysis. The authors hope to contribute significantly to improve teacher performance, add literature and enrich related science education management. Based on the above description, the authors raised the title, "Academic Supervision Principal toward Teacher's Performance Business and Management Group of VHS in Depok City through Work Motivation as Intervening Variable".

\subsection{Research Purposes}

The purpose of this study is to determine the influence of academic supervision of school principals on the motivation of teachers of Business Group and Management of State and Private VHS in Depok city, the influence of academic supervision of school principals on the performance of teachers Business Group and Management VHS State and Private in Depok city, Work motivation on teacher performance of Business Group and Management of State and Private VHS in Depok city.

\subsection{Literature Review}

\subsubsection{Teacher's Performance}

Performance is the result or level of success of a person as a whole over a certain period of time in carrying out the task compared with various possibilities, such as predefined work standard, target or criteria target and agreed upon. If seen from the origin he said, the word performance is a translation of the word performance, according to The Scribner-Bantam English Dictionary, published by the United States and Canada. Derived from the root of the word to perform with several entries: (1) performing, executing, executing (to do or carry out, execute), (2) fulfilling or implementing a discharge of fullfill, (4) doing what one would expect of a person is essentially what the employee does or does not do [2].

Furthermore, Ministry of National Education [3] defines performance with work performance or performance. Performance is a form of work or business results in the form of physical appearance, as well as ideas. Performance is often associated with competence in self-perpetrators. While Dharma [4] said 
Measuring the performance of individuals or organizations usually used as a reference normative performance standards. The performance indicators described divided into five areas: 1) Quality of work is the quality of the work, 2) Promptness is punctuality finish the job, 3) Initiative as an initiative in completing the work, 4) Capability is the ability to complete the work, and 5) Communications is the ability to foster collaboration with other parties. The above performance standards need to be formulated to be used as reference in conducting assessments, comparing what is achieved with what was expected. Performance standards are the benchmarks for comparing the performance achieved. Job satisfaction regarding the compatibility between one's expectations in return provided. Performance standards can be used as a benchmark to hold accountability for what has been done.

From some of the above opinions can be concluded that the performance of teachers is the action of a teacher in doing something desired in connection with teaching tasks, with certain results. This clearly requires the ability of mental, physical, objective and good insight about the program that is implemented thoroughly in performing duties and responsibilities as a teacher.

\subsubsection{Work Motivation}

Robbins and Judge [5] define work motivation as a process that explains the intensity, direction and persistence of effort to achieve a goal. Furthermore Mangkunegara [6] states that the motivation is formed from the attitude (attitude) employees in the face of work situations in the company (situation). Motivation is a condition or energy that moves the targeted or targeted employees to achieve the goals of the organization. The mental attitude of employees whose are pro and positive to the work situation that strengthens the motivation to work to achieve maximum performance. Motivation can be a set of attitudes and values that influence the individual to achieve specific things according to the individual's goals. Such attitudes and values are an invisible one that provides the power to encourage individuals to behave in achieving goals [7].

Furthermore according to Hasibuan [8] work motivations are a pleasant emotional attitude and love his job. This attitude is reflected by work morale, discipline, and work performance. Mean while, according Handoko [9] states that the motivation of work is a psychological process through the desire that has not been satisfied that is directed and pushed to the achievement of goals.

Based on some opinions above can be concluded that motivation is an impulse that arises in a person to want to do something in an effort to realize the goals that have been predetermined. Thus, the essence of that motivation is the existence of a kind of impetus or force that causes a teacher with a high awareness to carry out the tasks and responsibilities as determined. And motivation must be built in the teacher because with no motivation in a person it will facilitate the principals directing teacher to good performance

\subsubsection{Academic Supervision of Principal}

Supervision is an activity undertaken by the principal to assist teachers in developing their skills and facilitate teachers in improving the learning process [10]. The same thing was conveyed by Purwanto [11] supervision is a coaching activity planned to help teachers and other school staff in doing their work effectively.

From the above understanding, it can be simply understood that supervision is an attempt to compare the standard of a particular activity of what one planned with the implementation of the plan, as well as to follow up the results of the comparison. It's means that supervision should be able to make measurements on the results with a certain standard of activity. As stated by Moejikat [12] arguing that supervision is a process consisting of three important steps: 1) measuring the ability of teachers; 2) compare the teacher's ability with a plan, and see if there are deviations 3 ) correct unfavorable deviations by making improvements.

Principals with supervisory knowledge can be used to provide direction. This means that the principal has a strategy or an effective way to provide assistance in the form of guidance and direction. The principal with his knowledge can do his job not only to govern, but to be able to provide more effective work motivation. Similarly, Sagala [13] explains that supervision is the main idea in promoting professional growth of teachers to develop democratic leadership and solve the problems of teaching and learning effectively. To get the goal, it is done effective learning supervision in improving the quality of education from the effort to improve the cognitive value of student achievement in the subject which is at the high school level, as the previous Principal do problem analysis which then forwarded with problem identification and clarify it.

\subsection{Conceptual Framework and Hypotheses}

Systematically the influence of Principal Academic Supervision and Work Motivation on Teacher Performance can be seen in Figure 1.: 


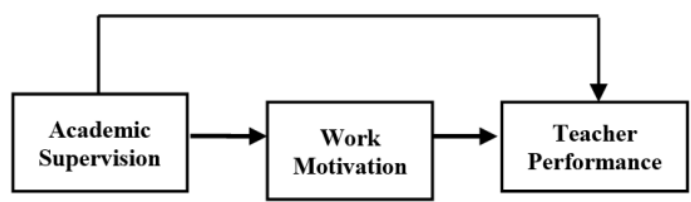

Figure 1. Conceptual framework

Based on literature review and previous research hence can be formulated hypothesis as follows:

a. Academic supervision has a significant effect on the motivation of teachers of Business and Management Group of State and Private VHS in Depok City.

b. Supervision has a significant effect on the performance of teachers of Business and Management Group of State and Private VHS in Depok City.

c. Motivation has a significant effect on the performance of teachers of Business and Management Group of State and Private VHS in Depok City.

\section{RESEARCH METHOD}

\subsection{Research Approach}

Based on the problems to be studied, this research is classified as descriptive and associative research with quantitative approach. This descriptive research is one form of research that aims to describe the event or the occurrence of variables in the study [14]. According Sugiono associative research is to predict how the influence of independent variables to the dependent variable then analyzed by regression [15].

\subsection{Population and Sample}

The population of this study is all teachers of Business and Management group of VHS in Depok City as many as 384 people. The data is in 11 schools, both state and private in 8 districts, among others; Cimanggis district, Beji district, Limo district, Pancoran Mas district, Cinere district, Sawangan district, Sukmajaya district and Tapos district.

Given the relatively large amount of teachers, the authors took samples from the existing population. The sampling technique used is the technique of Proportional Random Sampling [16]. To determine the amount of samples according to Slovin in Umar with the following formula [17]:

$$
n=\frac{\mathrm{N}}{1+\mathrm{N} \cdot \mathrm{e}^{2}}
$$

By using the formula above, it can be determined the sum of samples as follows:

$$
n=\frac{384}{1+384(0,01)}
$$

Then get the result $n=79.33$ people, rounded to 80 People. Based on the calculation of the sum of samples above, then the sum of research samples of each section is like table 1 below:

\begin{tabular}{lcc}
\multicolumn{2}{c}{ Table } & 1. Sum of Samples Each School \\
\hline No. & \multicolumn{1}{c}{ School } & Sample \\
\hline 1 & VHSS 1 Depok & 17 \\
2 & VHSS 3 Depok & 12 \\
3 & VHSP Insan Madani & 5 \\
4 & VHSP Yapan Indonesia & 8 \\
5 & VHSP Ganesa Satria 1 & 7 \\
6 & VHSP Panmas 2 & 6 \\
7 & VHSP Wisata Kharisma & 7 \\
8 & VHSP Lingga Kencana & 5 \\
9 & VHSP Putra Bangsa & 5 \\
10 & VHSP Winaya Loka & 4 \\
11 & VHSP Tadika Pertiwi & 4 \\
& Total & 80 \\
\hline
\end{tabular}




\subsection{Data Collection Technique}

Data Collection by giving or distributing a list of statements (questionnaires) about the principal's academic supervision, work motivation and teacher performance to the respondent with the expectation of respondents to respond to the list of statements. The list of statements is prepared using a Likert scale. Each question has five alternative answers, among others; Strongly Agree, Agree, Mediocre Only, Less Agree, and Disagree. In addition, it could also be a choice of answers; Always, Frequently, Sometimes, Rarely, and Never.

\subsection{Validity and Realibility Test}

Prior to using the research instrument, trials should first be done to obtain valid and reliable statement items then tested the validity and reliability test. Test the validity of the statement using the Correlation Product Moment (Pearson) and the reliability test by using Cronbach Alpha. The test validity and reliability test carried out minimal to 30 respondents. For $n=30, \alpha=0,05$. then, $r_{\text {tabel }}=0,361$ with Criteria: If $r_{\text {hit }}>r_{\text {tab }}$ : the instrument is said to be valid and reliable

if $r_{\text {hit }}<r_{\text {tab }}$ : the instrument is said to be invalid and not reliable.

\subsection{Data analysis technique}

Data analysis techniques used descriptive analysis and inferential analysis. Questionnaires that have been collected and then scored manually to produce accuracy, processed and analyzed with the help of SPSS version 23.0 for Windows. Furthermore, the inferential analysis first tested the classical assumption or prerequisite test such as normality test, homogeneity test. After the prerequisite test is completed, then the hypothesis test is continued. The analysis used is by path analysis

\section{RESULTS AND DISCUSSION}

\subsection{Descriptive Analysis}

\subsubsection{Frequency Distribution of Teacher's Performance}

The results of statistical calculations, the performance of teachers with indicators of work quality can be known to the average score of 4.30 with the level of respondents achievement is 86.00 . This figure is in the range $86 \%-100 \%$ can be said teacher performance on the indicator of quality work categorized very well. This means that the vocational school teacher in Depok city has a high quality of work, able to perform the task very good and reliably in developing practical solutions related to his work as a teacher.

Then on the indicator of the average score of 4.26 with the level of respondent's achievement equal to $85.19 \%$. This figure is in the range $71 \%-85 \%$. This means that teachers have a quantity of work that is related to the volume of output and contributions that can be said either. While on the indicator of timeliness, the level of respondent's achievement amounted to $89.50 \%$. This figure is in the range $86 \%-100 \%$ means the average teacher in the run and complete the task on the category very good. Furthermore, for the effectiveness indicator, the respondent's achievement rate is $88.75 \%$. This figure is in the range $86 \%-100 \%$. This means that the effectiveness of teachers in this case teachers use resources to support learning activities, both material and immaterial can be said very well. Then on self-reliance indicator, the respondent's level of achievement is only $85.25 \%$. This figure is in the range $71 \%-85 \%$. This means that the average teacher has an independent attitude in carrying out the task and can solve the constraints independently. Level of Respondent Achievement for teacher performance variables is $86.25 \%$. This means that on average the performance of vocational teachers in Depok City is categorized very well.

Table 2. Frequency Distribution of Teacher's Performance

\begin{tabular}{|c|c|c|c|c|c|c|c|c|c|c|c|c|c|c|}
\hline \multirow{2}{*}{ No. } & \multirow{2}{*}{ Indicator } & \multicolumn{2}{|c|}{ Always } & \multicolumn{2}{|c|}{ Frequently } & \multicolumn{2}{|c|}{ Sometimes } & \multicolumn{2}{|c|}{ Rarely } & \multicolumn{2}{|c|}{ Never } & \multirow{2}{*}{$\begin{array}{c}\text { Average } \\
\text { (mean) }\end{array}$} & \multirow{2}{*}{$\begin{array}{l}\text { LRA } \\
(\%)\end{array}$} & \multirow{2}{*}{$\begin{array}{l}\text { Answer } \\
\text { Category }\end{array}$} \\
\hline & & $F i$ & $\%$ & $F i$ & $\%$ & $F i$ & $\%$ & $F i$ & $\%$ & $F i$ & $\%$ & & & \\
\hline 1 & Quality of work & 42 & 52.50 & 24 & 30.00 & 11 & 13.75 & 2 & 2.50 & 1 & 1.25 & 4.30 & 86.00 & Very Good \\
\hline 2 & Quantity produced & 33 & 41.25 & 26 & 32.50 & 17 & 21.25 & 3 & 3.75 & 1 & 1.25 & 4.26 & 85.19 & Good \\
\hline 3 & Punctually & 46 & 57.50 & 27 & 33.75 & 6 & 7.50 & 1 & 1.25 & 0 & 0.00 & 4.48 & 89.50 & Very Good \\
\hline 4 & Effectiveness & 46 & 57.50 & 24 & 30.00 & 9 & 11.25 & 1 & 1.25 & 0 & 0.00 & 4.44 & 88.75 & Very Good \\
\hline 5. & Independence & 36 & 45.00 & 32 & 40.00 & 10 & 12.50 & 1 & 1.25 & 1 & 1.25 & 4.26 & 85.25 & Good \\
\hline & Variable Rate & 41 & 51.25 & 26 & 32.50 & 11 & 13.75 & 1 & 1.25 & 1 & 1.25 & 4.31 & 86.25 & Very Good \\
\hline
\end{tabular}




\subsubsection{Frequency Distribution of Work Motivation}

Based on the results of data processing, it is known that the variable work motivation with the indicator diligently in working score average of 4.35 with the level of respondent achievement for the indicator is $87.00 \%$. This figure is in the range of $86 \%-100 \%$, meaning teachers have a very high persistence. Then on the resilient indicators face difficulties in working can be known the average score is 4.33 and the level of respondent's achievement of $86.50 \%$. This figure is in the range $86 \%-100 \%$ which means that in general the teacher is able to solve the problem. The indicator of desire to succeed can be known average score of 4.34 level of respondent's achievement of $86.75 \%$. This figure is in the range of $86 \%-100 \%$, it means that the average teacher of VHS in Depok city has a very high desire to succeed in his work, in his effort to educate the learner.

Furthermore, teacher work motivation on indicators of need/drive in work can be known average score of 4.38 with the level of respondent achievement of $87.50 \%$. This figure is in the range of $86 \%-100 \%$ which means that teachers have a strong enough or good enough impulse to teach. They are well aware of everything that is needed for the teaching and learning process to run smoothly, learners feel satisfied and woke up a fun learning atmosphere.

On average, the level of respondents' achievement for work motivation variable amounted to $87.00 \%$. This figure is in the range of $86 \%-100 \%$ which means the work motivation of teachers VHS in Depok City is categorized very well.

Table 3. Frequency Distribution of Work Motivation

\begin{tabular}{|c|c|c|c|c|c|c|c|c|c|c|c|c|c|c|}
\hline \multirow{2}{*}{ No. } & \multirow{2}{*}{ Indicator } & \multicolumn{2}{|c|}{ Always } & \multicolumn{2}{|c|}{ Frequently } & \multicolumn{2}{|c|}{ Sometimes } & \multicolumn{2}{|c|}{ Rarely } & \multicolumn{2}{|c|}{ Never } & \multirow{2}{*}{$\begin{array}{c}\text { Average } \\
\text { (mean) }\end{array}$} & \multirow{2}{*}{$\begin{array}{c}\text { LRA } \\
(\%)\end{array}$} & \multirow{2}{*}{$\begin{array}{c}\text { Answer } \\
\text { Category }\end{array}$} \\
\hline & & $F i$ & $\%$ & $F i$ & $\%$ & $F i$ & $\%$ & $F i$ & $\%$ & $F i$ & $\%$ & & & \\
\hline 1 & Diligent in working & 44 & 55.00 & 23 & 28.75 & 11 & 13.75 & 1 & 1.25 & 1 & 1.25 & 4.35 & 87.00 & Very Good \\
\hline 2 & $\begin{array}{l}\text { Ductile face } \\
\text { difficulties in working }\end{array}$ & 39 & 48.75 & 28 & 35.00 & 13 & 16.25 & 0 & 0.00 & 0 & 0.00 & 4.33 & 86.50 & Very Good \\
\hline 3 & $\begin{array}{l}\text { Desire to succeed } \\
\text { Existence of }\end{array}$ & 42 & 52.50 & 25 & 31.25 & 11 & 13.75 & 2 & 2.50 & 0 & 0.00 & 4.34 & 86.75 & Very Good \\
\hline 4 & $\begin{array}{l}\text { encouragement/need } \\
\text { in work }\end{array}$ & 44 & 55.00 & 23 & 28.75 & 12 & 15.00 & 1 & 1.25 & 0 & 0.00 & 4.38 & 87.50 & Very Good \\
\hline & Variable Rate & 42 & 52.50 & 25 & 31.25 & 12 & 15.00 & 1 & 1.25 & 0 & 0.00 & 4.35 & 87.00 & Very Good \\
\hline
\end{tabular}

\subsubsection{Frequency Distribution of Academic Supervision}

Furthermore for the variable Supervision academic principal with the indicators of guidance to improve teaching can be known average score of 4.31 level of respondent's achievement is $86.25 \%$. This figure is in the range of $86 \%-100 \%$ can be interpreted very well. The indicator of effectiveness of the role of teachers and other material sources can be known average score of 4.11 with the level of respondents' achievement of $82.25 \%$. This figure is in the range $71 \%-85 \%$ can be interpreted that the principal is able to act well as supervisor, provide constructive directions to teachers in carrying out their duties to be effective. For indicators involving all school teachers and staff, the respondents' attainment rate was $86.00 \%$. This means that the principal in carrying out supervision always involves all teachers and school staff.

Then for the indicator to do good supervision technique, respondent's achievement level equal to $83,00 \%$. This figure is in the range $71 \%-85 \%$. This means that in doing a good supervision technique on the principal is said to be good.

The indicator to help teachers how to teach an effective average score of 4.15 . When viewed from the level of achievement of respondents for indicators to help teachers how to teach an effective amount of $83.00 \%$. This figure is in the range $71 \%-85 \%$. This means that in helping teachers how to teach effectively in the head of the school is said to be good.

Academic Supervision Principal can be known the total score is 4.21 with the level of respondent's achievement of $84.25 \%$. This means that the academic supervision performed by the principal can be said to be good. 
Table 4. Frequency Distribution of Academic Supervision

\begin{tabular}{|c|c|c|c|c|c|c|c|c|c|c|c|c|c|c|}
\hline \multirow{2}{*}{ No. } & \multirow{2}{*}{ Indicator } & \multicolumn{2}{|c|}{ SA } & \multicolumn{2}{|r|}{$\mathrm{A}$} & \multicolumn{2}{|c|}{$\mathrm{MO}$} & \multicolumn{2}{|c|}{ LA } & \multicolumn{2}{|c|}{ DA } & \multirow{2}{*}{$\begin{array}{l}\text { Average } \\
\text { (mean) }\end{array}$} & \multirow{2}{*}{$\begin{array}{c}\text { LRA } \\
(\%)\end{array}$} & \multirow{2}{*}{$\begin{array}{l}\text { Answer } \\
\text { Category }\end{array}$} \\
\hline & & $F i$ & $\%$ & $F i$ & $\%$ & $F i$ & $\%$ & $F i$ & $\%$ & $F i$ & $\%$ & & & \\
\hline 1 & $\begin{array}{l}\text { Conducting guidance } \\
\text { for improvement of } \\
\text { teaching }\end{array}$ & 36 & 45.00 & 34 & 42.50 & 9 & 11.25 & 1 & 1.25 & 0 & 0.00 & 4.31 & 86.25 & Very Good \\
\hline 2 & $\begin{array}{l}\text { Streamline the role of } \\
\text { teachers and other } \\
\text { material resources }\end{array}$ & 31 & 38.75 & 32 & 40.00 & 13 & 16.25 & 3 & 3.75 & 1 & 1.25 & 4.11 & 82.25 & Good \\
\hline 3 & $\begin{array}{l}\text { Involves the } \\
\text { participation of all } \\
\text { teachers and school } \\
\text { staff }\end{array}$ & 36 & 45.00 & 33 & 41.25 & 10 & 12.50 & 1 & 1.25 & 0 & 0.00 & 4.30 & 86.00 & Very Good \\
\hline 4 & $\begin{array}{l}\text { Perform good } \\
\text { supervision techniques }\end{array}$ & 32 & 40.00 & 32 & 40.00 & 13 & 16.25 & 2 & 2.50 & 1 & 1.25 & 4.15 & 83.00 & Good \\
\hline \multirow[t]{2}{*}{5.} & $\begin{array}{l}\text { Helping teachers to } \\
\text { teach effective ways }\end{array}$ & 24 & 30.00 & 44 & 55.00 & 12 & 15.00 & 0 & 0.00 & 0 & 0.00 & 4.15 & 83.00 & Good \\
\hline & Variable Rate & 32 & 40.00 & 35 & 43.75 & 11 & 13.75 & 2 & 2.50 & 0 & 0.00 & 4.21 & 84.25 & Good \\
\hline
\end{tabular}

\subsection{Inferential Analysis}

Based on hypothesis testing, it can be seen the direct and indirect effect of independent variable through intervening variable to the dependent variable as follows.

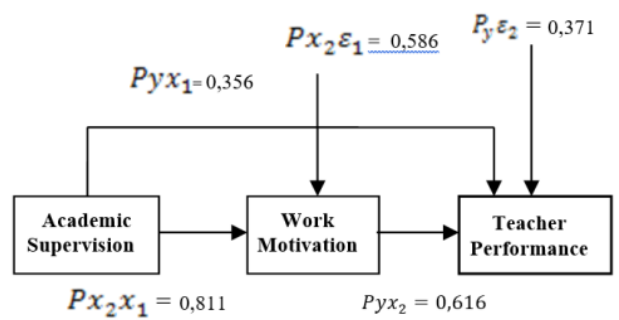

Figure 2. Direct and Indirect Influence between Independent Variables through Intervening Variables of Dependent Variables

In the following table it can be seen clearly the direct and indirect effects of causal variables and consequent variables

Table 5. Direct and Indirect Effects of Variable Causes, Intermediate Variables and Variable Effects

\begin{tabular}{clccc}
\hline No. & \multicolumn{1}{c}{ Variables } & Indirect & $\begin{array}{c}\text { Effects } \\
\text { Direct }\end{array}$ & $\begin{array}{c}\text { Total } \\
(\%)\end{array}$ \\
\hline 1. & $\mathrm{X}_{1}$ to $\mathrm{Y}$ & - & 0,1267 & 12,67 \\
2. & $\mathrm{X}_{1}$ to $\mathrm{Y}$ through $\mathrm{X}_{2}$ & 0,1778 & - & 17,78 \\
3. & $\mathrm{X}_{2}$ to $\mathrm{Y}$ & - & 0,3794 & 37,94 \\
4. & Influence of Other Variables & - & - & 37,10 \\
\hline
\end{tabular}

\subsubsection{The First Hypothesis}

Obtained $t$ count $=12,227$, while $t$ table $=1,991$. It shows that $t_{\text {hit }}>t_{\text {tab }}(12,227>1,991)$, concluded the null hypothesis $\left(\mathrm{H}_{0}\right)$ is rejected. This means that Academic Supervision Principal has a significant effect on Work Motivation.

\subsubsection{Second Hypothesis}

Obtained $t$ count $=4.939$ while $t$ table $=1.991$ this shows that $t_{\text {hit }}>t_{\text {tab }}(4.939>1.991)$, it can be concluded that the null hypothesis $\left(\mathrm{H}_{0}\right)$ is rejected. This means that the Principal Academic Supervision has a significant effect on Teacher Performance. 


\subsubsection{Third Hypothesis}

Obtained $t$ count $=8,534$ while $t$ table $=1,991$. This shows that $t_{\text {hit }}>t_{\text {tab }}(8,534>1,991)$, it can be concluded that the null hypothesis $\left(\mathrm{H}_{0}\right)$ is rejected. This means that Work Motivation has a significant effect on Teacher Performance

\subsection{Discussion}

\subsubsection{The Effect of Academic Supervision of School Principal on Teachers' Work Motivation of} Business Group and Management of State and Private VHS in Depok City

Based on the hypothesis testing there is a significant positive effect of Principal Academic Supervision on Work Motivation Teachers Group Business and Management VHS Depok City. This means that if Supervision Principal good, in this case the principal performs good supervision techniques, provide coaching and encouragement and follow up the problems faced by teachers, the better Master Work Motivation. Conversely, if the Principal Academic Supervision is not good or even ineffective, looking for errors, being arrogant, then the Work Motivation on the teacher will be worse because teachers feel depressed, stressful work and only pure discipline mentality that happens to the teacher, so that it implies a false motivation.

According to Handoko several factors that influence motivation are leadership, compensation, education, training, work climate, and work stress [9]. Reinforced by research findings Eleanor and Chang [18], Muhammad et. al. [19].

\subsubsection{The Effect of Academic Supervision of Principal on Teacher Performance of Business Group and Management of State and Private VHS in Depok City}

Based on the hypothesis testing, it is found that the Principal Academic Supervision has a significant positive effect on the Performance of Teachers Group Business and Management of VHS Negeri and Private Depok City with directly or indirectly. From the results of the analysis can be seen the direct influence of Academic Supervision Principal to Performance Teachers less influence that is only $12.67 \%$ compared to indirect influence through Job Motivation and that is equal to $17.78 \%$. This is because the results of the descriptive analysis indicate the Principal Academic Supervision of the smaller TCR is $84.25 \%$ and TCR Motivation Work of $87.00 \%$. Therefore Motivation Work function can be regarded as intervening variable. From the exposure, it can be concluded the meaning is that to improve Teacher Performance, not only Motivation Work that needs to be improved. However, it must first be improved Academic Supervision Principal. Strengthened by the results of research Veloo, et al [20], Radjbar et al [21], Ikegbusi et al [22], Li et al [23], also Ashlan [24].

\subsubsection{The Effect of Work Motivation on Teacher Performance of Business Group and Management of State and Private VHS in Depok City}

Based on hypothesis testing, it was found that Work Motivation has a significant positive effect on the performance of Teachers Group Business and management of VHS Negeri and Private in Depok City. It can be interpreted that very good Motivation Work tends to improve Teacher Performance. Conversely, if Motivation Work drops drastically, it will result in teachers tend to be lazy, less than optimal in teaching that implicates in poor performance. The results of this study support previous research by Akuoko and Donkor [25], Shehnaz and Noor Ul Hadi [26], Lipsey et al. [27], Muhammad et.al [28], Meindinyo R. O K, and Ikurite N [29-30], Denny Denmar and Sri Marmoah [31], and Idris, Muhammad [32].

Various studies have been made as references, which are interesting in this study and certainly in comparison with previous studies are the use of analytical techniques. As far as the author's knowledge, the independent variables in this study are always treated with regression analysis techniques with simple regression and multiple regressions. Therefore, the author tries through a path analysis approach, where the variable of work motivation as a standing variable. This is to complement new things, improvements, and effective strategies for implementation of research results.

\section{CONCLUSION}

Based on the results of research and discussion about the influence of academic supervision of principal and work motivation on teacher business group performance and management of VHS Negeri and Swasta in Depok city, the authors conclude that the principal academic supervision has a significant positive effect on teacher performance Business group and management of VHS Negeri Private in Depok city with directly and indirectly through work motivation.

Work motivation function as intervening variable because in descriptive analysis obtained level of achievement respondent of work motivation bigger than level of respondent achievement academic 
supervision. This means that to improve teacher performance, not only motivation of work which needs to be improved. However, the academic supervision of the principal must be increased first.

\section{ACKNOWLEDGEMENTS}

Research and writing of this journal is funded by Kemristek Dikti DIPA: Directorate of Research and Community Service No. Contract: 0428/K3/KM/2017 with "Penelitian Dosen Pemula (PDP)" scheme. Therefore, the authors thank the infinite. This is a pride for the author and an opportunity for authors to develop capacity. The authors express their sincere appreciation to all principals, vice principals, teachers and all school staff who have been pleased and participated until the research is completed.

\section{REFERENCES}

[1] Wibowo. Manajemen Kinerja, Edisi Ketiga Jakarta: Rajawali Press; 2010

[2] Mangkuprawira, S. Bisnis, Manajemen, dan SDM. Bogor: IPB Press; 2008

[3] Ministry of National Education, 2005. Law Number 14 Year 2005, About Teachers and Lecturers, Jakarta: Depdiknas.

[4] Dharma, Surya. Manajemen Kinerja. Jakarta: Kementerian Pendidikan Nasional dan Kebudayaan; 2008, p. 20

[5] Robbins, S. P. and T. A. Judge. Organizational Behavior. New Jersey: Pearson Education, Inc; 2007

[6] Mangkunegara, Anwar Prabu. Manajemen Sumber Daya Manusia Perusahaan. Bandung: PT Remaja Rosdakarya; 2009

[7] Rivai, Veithzal. Kepemimpinan dan Perilaku Organisasi. Jakarta: Rajawali Pers; 2008

[8] Hasibuan, Melayu S.P. Manajemen Sumber Daya Manusia Edisi Revisi. Jakarta: Bumi Aksara; 2011

[9] Handoko, T. Hani. Manajemen Personalia dan Sumber Daya Manusia. Yogyakarta: BPFE; 2008

[10] Mulyasa, E. Manajemen dan Kepemimpinan Kepala Sekolah. Jakarta: PT Bumi Aksara; 2011

[11] Purwanto, Ngalim. Administrasi dan Supervisi Pendidikan. Bandung: PT Remaja Rosda Karya; 2010

[12] Moekijat. Analisis Jabatan. Bandung: CV. Mandar Maju; 2008

[13] Sagala, Saeful. Supervisi Pembelajaran dalam Profesi Pendidikan. Bandung: PT Remaja Rosda Karya; 2010

[14] Prasetyono, Hendro. "Graduate Program Evaluation in the Area Leading Educational, Outlying and Backward". Journal of Education and Practice, vol. 7. No. 36, pp. 109-116, 2016

[15] Sugiyono. Statistik Non Parametrik untuk Penelitian. Bandung: Alfabeta, p. 249; 2009

[16] Sugiono. Metode Penelitian Kuantitatif, Kualitatif, dan R\&D. Bandung: Alfabeta, p. 68; 2012

[17] Umar, Husein. Metode Penelitian untuk Skripsi dan Tesis Bisnis. Jakarta: Rajawali Pers; 2009.

[18] Eleanor Bodden Gillett and Wei-Wen Chang. "Strategies Used by Principals to Motivate Teachers in Secondary Institutions in Belize". Journal International Cooperation, vol. 4 No. 1, pp. 83 - 100, 2009

[19] Muhammad Ridwan, Nurzila, Abdullah Saman, Maisah. "The Relationship of Educational Supervision Supervisory Knowledge to Guidance and Labor Education Teacher Motivation Work in the Madrasah Aliyah Jambi City". International Journal of Science and Research (IJSR), vol. 5 Issue 8, pp.101-106, 2016

[20] Arsay Thamby Veloo, Mary Macdalena, A. Komuji, and Rozalina Khalid. "The Effects of Clinical Supervision on the Teaching Performance of Secondary School Teachers". Procedia-Social and Behavioral Sciences, vol. 93, pp. $35-39,2013$

[21] Hoojqan Ali Ranjbar, Jaafar Gharamani and Seyed Ali Safari. "The Effect of Educational Supervision on Improving Teachers' Performances in Guidance Schools of Marand”. Indian Journal of Fundamental and Applied Life Sciences, vol. 5 Issue 2, pp. 1731 - 1735, 2015

[22] Ikegbusi, Njideka Gloria, Dr. Eziamaka, Chika Nonye. "The Impact of Supervision of Instruction on Teacher Effectiveness in Secondary Schools in Nigeria". International Journal of Advanced Research in Education \& Technology (IJARET), vol. 3 Issue 3, pp. 12 - 16, 2016

[23] Lijuan Li, Philip Hallinger, James Ko. "Principal Leadership and School Capacity Effects on Teacher Learning in Hong Kong", International Journal of Educational Management, vol. 30 Issue 1, pp. 76 - 100, 2016

[24] Ashlan, Said. "Implementing the Teaching Supervision by Principals in Improvingthe Performance of Teachers in Aceh Besar". Jurnal Ilmiah Peuradeun, International Multidisciplinary Journal, vol. 5 No. 1, pp. 25 -36, 2017

[25] Akuoko, K. O and Dounkor, Doris. "Motivation and Performance of Teachers in Slected Second Cycle Institutions in the Ejitsu-Juaben Municipality, Ashanti Region, Ghana". International Journal of Business and Management tomorrow, vol. 2 No. 9, 2012

[26] Shehnaz Tehseen, Noor Ul Hadi. "Factors influencing Teachers' Performance and Retention". Meditteranean Journal of Social Sciences, vol. 6 No 1, pp. 233 - 244, 2015

[27] Lipsey Samuel Appiah Kwapong, Emmanuel Opoku and Fokuo Donyina. "The Effect of Motivation on the Performance of Teaching Staff in Ghanaian Polytechnics: The Moderating Role of Education and Research Experience". Global Journal of Human Resource Management, vol.3. No. 6, pp. 30 - 43, 2015

[28] Muhammad Imran Rasheed Asad Afzal Humayon Usama Awan Affan ud Din Ahmed. "Factors affecting teachers' motivation", International Journal of Educational Management, vol. 30 Issue 1, pp. 101 - 114, 2016

[29] Meindinyo R. O K, and Ikurite N. "Influence Of Motivation On Teachers Performance In A Local Government Area In Nigeria". IOSR Journal Of Humanities And Social Science (IOSR-JHSS), vol. 22, Issue 5, Ver. 3, pp. $22-28,2017$ 
[30] Meindinyo R. O K, and Ikurite N. "Influence of Motivation On Teachers Performance In A Local Government Area In Nigeria”. IOSR Journal Of Humanities And Social Science (IOSR-JHSS), vol. 22, Issue 5, Ver. 3, pp. $22-28,2017$

[31] Denny Denmar and Sri Marmoah. "The Relationship Between Job Environment, Job Motivation, And Teachers Performance" IOSR Journal Of Humanities And Social Science (IOSR-JHSS), vol. 22, Issue 6, Ver. 3 (June. 2017), pp $52-60,2017$

[32] Idris, Muhammad. "The Impact of Supervision, Motivation and Work Ethic on Teachers' Professional Competence: A Case Study of Private Islamic High School Teachers". International Journal of Human Resource Studies, vol. 6, No. 1, pp. 147 - 158, 2016 